\title{
11 Reflecting on Educational Experiences
}

\author{
An Analysis of Two Migrant \\ Students' Stories
}

\author{
Ragnar Arntzen and Odd Eriksen
}

\section{Introduction}

Whereas young people in stable societies can regard their educational careers as relatively plannable and predictable, many migrant students face changes and obstacles which can result in both educational and linguistic setbacks. In addition to the potential long-lasting effects of growing up in conflict areas and pulling up their roots, students with migration backgrounds struggle with studying, learning languages and integrating into society, among numerous other issues. Clearly, teachers have difficulty anticipating the challenges of this group of students. One way of identifying such challenges, however, is to encourage students to tell their stories. In bio-ecological theory, Bronfenbrenner $(2005,5)$ claims that the "scientifically relevant features of any environment for human development include not only its objective properties, but also the way in which these properties are subjectively experienced by the person living in that environment". Accordingly, Clandinin, and Connelly (2000) emphasise the need to study participants' experiences in educational research. In conversations with students, stories "emerge through the interaction or dialogue of the teacher (or researcher) and the participant" (Creswell 2013, 71). The activity of storytelling increases students' awareness of the consequences of the choices they have made in different learning situations as they reflect on their interactions with their learning environment in various periods of their lives.

This chapter reports on data from a study exploring migrant students' experiences with education across cultures. Through semi-structured interviews with two teacher students, we aimed to contribute to the students' construction of their educational histories in order to obtain multicultural perspectives on the Norwegian educational system. We focused on the environment in which the students were socialised, their descriptions of the development of their lives, and the choices they have made while in the school system. We believe that asking the students to tell their stories allowed them to become aware of and learn about their choices and paths through the educational system. Students' feelings of self-efficacy might also be increased by reflecting on their experiences. To capture the significance 
of the students' educational experiences, we adopted a narrative inquiry approach. In addition, teachers can benefit from developing increased awareness and interest in students' stories and from reflecting on new possibilities for improving learning and building knowledge in their classrooms.

\section{Literature Review}

\section{Studies on Migrant Students' Educational Experiences}

Much of the literature on minority students' access and retention in higher education has focused on structural barriers rather than on how students reflect on and negotiate these barriers (Oropeza, Varghese, and Kanno 2010, 217). Here we will present some qualitative studies wherein migrant students reported their own thoughts and reflections. Martin (2010) studied the intersection of higher education, language and identity in four migrant graduates' stories in the UK. In these stories, he found "clear evidence of racism, exclusion and cultural entanglement" (Martin 2010, 17). However, the stories also contained evidence of pride and empowerment in cases where students were given space to talk about their multicultural and multilingual lives. All too often, however, education, especially higher education, seems to ignore the rich cultural and linguistic resources of the increasingly diverse student communities, according to Martin (2010).

Oropeza, Varghese, and Kanno (2010) interviewed four migrant students in higher education in the US, focusing on how the students made use of the community's cultural wealth and different forms of capital to access college and to what extent the students felt their cultural capital was relevant in this new educational environment. The students expressed the importance of aspirational capital in pursuing higher education and connected it to their familial capital. They also developed social capital through their family or by negotiating the labels and categorisations they were given in the schools and at the college (Oropeza, Varghese, and Kanno 2010, 228). On the other hand, the students did not perceive their multilingualism as carrying much value within the university; rather, it was their lack of linguistic capitalbeing linguistic minorities-that was accentuated in their pathway to and through college (227). The students also reported lack of familiarity with US culture and English as constituting barriers to their access to educational opportunities (227).

Berge (2012) interviewed eight university students with migrant backgrounds. The informants' dominant language in early childhood was a first language (L1) other than Norwegian, but Norwegian became their dominant language later in life. The students felt that their multicultural and multilingual resources were neglected throughout their education. For example, most students reported that they had either forgotten much of their mother tongue or had become less proficient in it. The informants spoke Norwegian, their second language (L2), even with friends who shared the same L1 
because they felt more confident in Norwegian and could express more of its nuances (Berge 2012, 40). Other studies have confirmed this tendency. Berggreen and Latomaa (1994) found that children and youth more commonly use the majority language (L2) when they communicate than adults do, and that siblings use the majority language with each other at home (Berggreen and Latomaa 1994; Kulbrandstad 1997). These different language use patterns of younger and elder generations are also confirmed in international literature (Pauwels 2016). The change in the dominant language by Berge's (2012) informants complicated their contact with their families, even informants whose family language in childhood was Norwegian. Furthermore, informants' conversations with their parents were limited to everyday topics, impeding mutual involvement in their lives (Berge 2012, 35). For a broad discussion of this topic, see Fillmore (2000).

For Berge's (2012), Oropeza, Varghese, and Kanno's (2010) and Martin's (2010) informants, their mother tongue (L1) played a marginal role in their schools and education. As adults, Berge's (2012) informants were far more motivated to learn Western European languages than to develop their skills in their mother tongue. Several students looked at instruction in their mother tongue as a burden and a negative experience, one which "deprived [them] of playtime" (Berge 2012, 32). One of Martin's (2010) informants experienced mother-tongue teaching as punishment and kept it a secret from friends.

Migrant students sometimes experience problems identifying with their host countries. Among Berge's $(2012,33)$ informants, the university students born and raised in Norway did not identify completely with other Norwegians: "We do not feel at home any place; we are not completely Norwegian, and we do not feel at home in our parents' homeland either. I do not completely belong to any culture". This theme was also strongly emphasised by Martin (2010), as reflected in the article title, "They Have Lost Their Identity, but not Gained a British One", which quotes an essay by his informant.

Bourdieu $(1996,61)$ describes how cultural and linguistic coordination in a society establishes legitimate culture and language, which renders all other cultures and languages as less worthy or marginalised. The educational system privileges some students by taking their knowledge as the norm. When cultural capital is instituted in this way, stressing the need for all to possess one kind of linguistic and cultural competence, and open access to the means to satisfy these demands is not provided, only some become part of the legitimate cultural and linguistic circles that constitute symbolic power in society. Yosso (2005) has, in the lens of critical race theory, questioned how Bourdieu's theory has been used to evaluate some communities as culturally poor and assessed coloured students as "deficient" as the theory focuses on how they fall short of the white, middle-class standard. Yosso asks whether there are forms of cultural capital "that marginalised groups bring to the table that traditional capital theory does not recognise 
or value" (Yosso 2005, 77). Her alternative approach is to focus on "community cultural wealth" (69), valuable resources possessed by communities of colour, as aspirational, navigational, familial and linguistic capital. But these valuable resources pertain not only to race and colour, but all types of minority communities and groups. As a foundation for creating functional identities in host countries, migrant students need to be respected for their personal histories and backgrounds and supported in their efforts to acquire new cultural codes. Several studies from previous decades have shown that culturally diverse universities create varied educational experiences that can help students learn and prepare for participation in complex and diverse societies (Denson and Bowman 2013, 557).

\section{Some Cognitive and Linguistic Effects of Being Multilingual}

Since Peal and Lambert (1962), a considerable body of data has been collected suggesting that bilingualism and multilingualism have a number of positive cognitive effects, such as increased metalinguistic and metacognitive awareness, stronger problem-solving skills and greater attentional control (Jessner 2018, this volume; Adesope et al. 2010). A meta-analysis of 63 studies involving approximately 6,000 participants shows several positive cognitive effects in favour of bilingualism, where attentional control produced the largest effect (Adesope et al. 2010, 228f). Also, Bialystok and Poarch $(2014,437)$ claim that attentional control is the most beneficial cognitive effect of bilingualism, which means that bi- and multilingual speakers are more readily able to control their attention while engaged in linguistic and nonverbal tasks compared to monolingual learners. Bialystok has worked in this field since the 1980s; in a 1988 study, she found that children who differ in their level of bilingualism possess different advantages in solving metalinguistic problems compared with monolingual children (Bialystok 1988, 566).

The linguistic consequences of bilingualism seem surprisingly disadvantageous compared to monolingualism (Bialystok and Poarch 2014, 435f). These disadvantages concern both vocabulary quality and size and access to specific lexical entries (436). However, when comparing the vocabulary size of mono- and bilinguals, one has to keep in mind the overlapping conceptual vocabulary of bilingual children; bilinguals often know words for concepts in one language, but not the other. Vocabulary scores in one language therefore do not reflect bilingual children's complete linguistic knowledge (Bialystok and Poarch 2014, 436). On the other hand, it is obvious that constraints in bilinguals' vocabulary in the language of instruction will make reading comprehension of demanding textbooks and other language learning and performance tasks more challenging. Rydland, Aukrust, and Fulland (2012) found a positive and significant correlation between vocabulary depth and prior topic knowledge among fifth-grade students. This correlation suggests that students with limited vocabulary depth in their L2 are less 
able to use their prior knowledge when reading and comprehending texts (Rydland, Aukrust, and Fulland 2012).

Cummins (2000) argues that knowledge and cognitive skills belong to a common underlying proficiency that is easily transferred from one language to another; therefore, the language in which students have the strongest skills should be used in subject instruction and teaching. Briefly stated, Cummins (2000) believes that, in the course of learning one language, a child acquires a set of skills and implicit metalinguistic knowledge that can be drawn upon when working in another language. This common underlying proficiency (CUP) provides the basis for the development of skills in both the L1 and L2. It follows that any expansion of the CUP that takes place in one language will have a beneficial effect on any other language (Cummins 2000).

It is important to note that researchers who find cognitive benefits have focused mostly on balanced bilinguals functioning at high levels (Adesope et al. 2010; Baker 2006; Bialystok and Poarch 2014). By the threshold hypothesis, Cummins (1976) states that learners must develop both languages at an age-appropriate level ( high level) to have cognitive advantages over monolinguals. The threshold hypothesis contains two more thresholds: a middle level, at which a student, such as a partly bilingual child, has ageappropriate skills in only one language, which brings no cognitive effects; and the bottom level, at which the learner has inadequate competence (incomplete acquisition) in both the L1 and L2, which can have negative cognitive effects (Baker 2006). Carlisle et al. (1999), for instance, found that those in the early stages of bilingualism do not reap benefits until they have developed sufficient vocabulary in both languages.

It is reasonable to assume that the cognitive and metacognitive benefits of bi- and multilinguals might be useful to migrant students within classrooms. Nevertheless, teachers (and researchers) in diverse classrooms often focus on the many challenges for migrant students instead of their advantages. In a study of students' strategic competence in bilingual and monolingual schools in France and Switzerland, Moore $(2006,136)$ found that multilingualism is not "an asset per se, when children are not encouraged in the school situation to rely on their different languages and language knowledge as positive resources". Along the same line, Baker (2006) stresses that good bilingual development to a large degree relies on supplying contexts for bilingualism, both in families and the broader society (see Haukås 2015, 2016 for similar viewpoints).

Different countries provide rather different contexts for bilingualism (Adesope et al. 2010, 229). In some countries, the school authorities encourage immigrants to maintain their native language while acquiring the instructional language, while other countries have a more unilingual policy. In Norwegian compulsory schools, pupils speak more than 180 languages (Statistics Norway 2013b), but we have little knowledge of 
the extent to which children and youth use their linguistic resources at school (Pran and Holst 2015). We also lack empirical knowledge about the effects of different linguistic pedagogical programmes for minorityspeaking students (Bakken 2007). However, a recent nationwide survey (Pran and Holst 2015) among pupils and teachers in primary and lower secondary schools in Norway found that multilingualism is neglected in classrooms even though governmental documents emphasise multilingualism as a resource. A majority of teachers did not thematise multilingualism in their teaching despite pupils' linguistic diversity. Additionally, several students experienced language-related teasing by fellow students (Pran and Holst 2015).

Another factor that might influence the cognitive effects of bilingualism is the age of onset of L2 (Montrul 2008). The meta-analysis of Adesope et al. (2010) suggests that the early onset of L2 is more likely to be associated with greater metalinguistic and metacognitive awareness (229). Adesope et al. $(2010,231)$ call for investigations on correlates of bilingualism within educational contexts and how students and their teachers may capitalise on these advantages.

\section{The Current Study}

\section{Aims and Research Questions}

The literature review above provides a contextual background for the present study. It was centred around previous studies on migration students' educational experiences and the potential cognitive and metacognitive benefits and challenges of being bi- or multilingual. The review showed that there are abundant data suggesting that multilingualism might have a number of positive cognitive and metacognitive effects if multilingual skills are balanced and supported by families and the educational and societal context. Most research on migrant students in higher education is, however, problemoriented, and has focused on structural barriers rather than on how students reflect on these barriers. Especially in a Norwegian context, there is a lack of studies focusing on successful migrant educational stories, particularly studies where students can tell such stories themselves. In this study, we wanted to capture migrant students' own stories about how they have succeeded in their path from lower to higher education. To do so, we adopted the narrative inquiry approach, which "sheds light on the identities of individuals and how they see themselves" (Creswell 2013, 71). The purpose of narrative inquiry is to understand the experiences of both the researcher and the participant (Clandinin and Connelly 2000). The deeper understanding of oneself that can arise from the narrative process can well be described as a foundation for students' metacognition, defined by Haukås (2018, this volume) as awareness of and reflections on one's knowledge, abilities and 


\section{Ragnar Arntzen and Odd Eriksen}

learning. This insight into individual students' stories about their experiences can also be an important tool in the development of good teaching skills. Clandinin and Connelly $(2000,2)$ viewed narrative inquiry as crucial to thinking about education: "as we think about a child's learning, a school, a particular policy, there is always a history, it is always changing, and it is always going somewhere". From this perspective, teachers in general could benefit from developing increased awareness and interest in students' stories and from reflecting on new possibilities for improving learning and building knowledge.

In our narrative project, we aimed to motivate our students to construct coherent social and cultural stories. This process makes students' stories available for systematic analysis and permits retrieving unique experiences, possible patterns, and their relation to the challenges in the overall field of education (Creswell 2009). Breckner (2005, as cited by Lutz 2011) argues that migration is distinguished from other life events, as it is transversal. Migration can occur at any time in life and consequently does not have a socially defined place in an ordinary life story or biography. In identity construction, migration is not linked to initiation procedures; it has no celebrations or anniversaries. It simply has no social script. Consequently, migrants have to work individually to integrate their migrant experiences into their life stories (Lutz 2011). Biographical interviews such as those presented here can be a relevant pedagogical tool to assist migrant students in this demanding identity-construction process.

These narratives can allow students to perceive how transversal events have led to their choices, whose consequences explain their present-day situations. Creswell $(2009,4)$ describes this kind of qualitative research as "a means for exploring and understanding the meaning individuals or groups ascribe to a social or human problem". According to Stølen (2013, 233), the aim of students' life stories is to articulate 'knowledge on substantial information about things that matters for the teachers and students in the classroom. In a life story perspective, the researcher can contribute to the process of making knowledge based on people's life experiences visible' (translated by the authors).

Based on this, our research questions for the present study were formulated as follows:

To what extent has the Norwegian educational system facilitated the transmission of migration students' previously acquired knowledge, linguistic and cultural resources?

How did migration students experience changes and challenges during primary and secondary school, and how did they reflect on this after entering higher education?

How can migration students' narratives influence and broaden teachers' and teacher educators' perspectives on education in a multicultural society? 


\section{The Context of the Study}

There are no statistics on the exact number of Norwegian elementaryschool students with migration backgrounds, but we know that approximately $17 \%$ of the Norwegian population has "migration backgrounds", i.e. they are first or second-generation migrants (Statistics Norway 2017). This percentage is rapidly increasing due to massive migrations of refugees and other people into Europe and, specifically, Norway.

The variation in migrants' educational experience is considerable and partly related to the country of origin. Immigrants aged 30-44 years from the Philippines, Poland, Russia, India, China and Iran, for instance, have a higher average level of education than the general public in Norway (among the same age group). However, one-third of all Thai, Turk and Pakistani migrants living in Norway have completed only primary school (Statistics Norway 2013a). Furthermore, many non-Western women are not included within the educational system. Women from Western countries have a higher average level of education than men. The opposite trend is present among immigrant groups from some non-Western countries, such as Somalia and Afghanistan.

These figures create a complex picture and indicate both great opportunities and major challenges concerning immigrant students and the extent to which immigrant groups can succeed in the Norwegian educational system.

\section{Participants}

The two participants in this study are part of a larger study consisting of eight students (two male, six female) from a university college in Norway. The students were recruited based on our knowledge of potential candidates and on contact with programme coordinators. The inclusion criteria were migration to Norway at some point in one's life and qualification for higher education. The students were informed by email about the aims and purposes of the project, and further details were given at the beginning of the interviews. The students' age at arrival in Norway varied from five to 28 years. Their countries or regions of origin were Albania (1), Kurdis$\tan (3)$, Afghanistan (2), Ukraine (1) and Greece (1). One student completed all his schooling in Norway, while others entered the Norwegian educational system in late primary or secondary school. Some had studied at universities in their homeland before entering our university college.

In this study, we highlight the stories of two students, each representing one of two contrastive perspectives. The two students focused on quite similar challenges, but selected different coping strategies. One student arrived in Norway at age ten, and the other at age 16; both were in their mid-20s at the time of the interview. Further information about the two students will be presented in their stories. 


\section{Ragnar Arntzen and Odd Eriksen}

\section{Procedure}

The interviews were audio-recorded, transcribed and sent to the participants to comment on. In the transcriptions, we used standard Norwegian orthography, and did not mark pauses, hesitations and reformulations. The purpose was to enhance the content, not to focus on the participants' L2 performance. The participants granted permission to use the anonymised materials in teaching and research.

The semi-structured interviews each lasted about one hour. We used an interview guide which created a framework for constructing the participants' life-stories from an educational perspective. We asked participants questions about their childhood, early schooling, language learning/use, migration and reflections on crucial changes in their educational and social development. We sought to create an open, friendly atmosphere so that the participants felt free to tell their stories. We used our experiences as educators to facilitate the students' process of reflecting while looking back at their lives. We conducted the interviews in Norwegian, and no participant felt this to be a disadvantage, as they all had developed advanced conversational skills in Norwegian. Overall, the participants seemed motivated to share their stories and discuss the challenges they encountered. It should be noted that the two participating students in this study have both read and approved the manuscript.

\section{Results}

\section{Babet's Story}

Babet is a Kurdish girl from northern Iraq. She attended a Kurdish school for four and a half years before moving to Norway with her mother and younger brother. Babet lived in a big city in Kurdistan, and the family settled in a small village in rural Norway, where Kurdish peers befriended them and facilitated their transition emotionally and socially. During the interview, Babet discovered a strategic pattern for her behaviour when she moves to new places and starts new schools. She prefers contact with peers with the same cultural and linguistic backgrounds: "I feel more comfortable when I am together with the Kurdish students, so when I have them, I don't need the Norwegians". She also recognises, while telling her story: "I have someone else to lean on, but that may not be so smart in the long run". As she has become more fluent in Norwegian, Babet has had some contact with Norwegians, but only at school. In leisure activities, she has never mingled with Norwegians.

Babet started learning in Norwegian schools in the fifth grade and felt like she had to start over from scratch: "I had no benefit from earlier schooling at all when I started in fifth grade in Norway. It had nothing to do with each other. It was a different world: the system itself is completely different". 
Babet and her Kurdish-speaking friends received mother-tongue support, but Babet did not have any positive experiences with this support:

Sometimes, a man came and took us Kurds out of the class. He told us about the background of Kurds and Kurdistan, but this was actually of no help for us. He only spoke Kurdish, and it was just fussy. I didn't get anything out of it, in fact. We spoke Kurdish, played on computers, had fun and so on, but this was not teaching.

Although Babet preferred Kurdish-speaking friends, she did not seem interested in preserving and developing her knowledge of Kurdish culture and language. Her family took a pragmatic attitude toward education and culture: "My parents wanted me to focus on the Norwegian language. They didn't think Kurdish was important for me because they knew I would complete my education in Norway". However, some of Babet's school problems seemed to be related to her way of handling bilingual contexts. In the lower secondary school, she understood everything at school, but struggled with writing: "I probably wrote how I thought inside my head in Kurdish, and then I translated it into Norwegian, and then the sentences become wrong". These problems continued. In the upper secondary school, she also separated from her Kurdish-speaking friends who chose other programme subjects: "I lost my friends. I lost faith, too!" However, she completed upper secondary school and advanced into higher education.

Babet started studying preschool-teacher education based on the advice of friends, who told her it was an easy study programme. However, she experienced difficulties and found that she did not like the work ("to be outdoors in the winter"). She found it hard to contact her teachers as they seemed so stressed. She also had no contact with ethnic Norwegian students and felt that they tried to avoid being in work groups with migrant students. Several course requirements were meant to be fulfilled in groups, and as a result, some migrant students like Babet had difficulties doing the tasks. At the time of the interview, Babet had not done all the requirements from the previous year and did not have a plan to fulfil them and pass the examinations.

\section{Yasmin's Story}

Yasmin was born and raised in Kabul during the Soviet-Afghan war. She and her family moved back and forth between Kabul and the Soviet border during the years of intensive bombing. From age six until ten, Yasmin was educated mostly by her parents, uncles and aunts at home or in refugee camps at the border. When Yasmin was ten years old, she and her family moved to Moscow, where they lived until they immigrated to Norway when she was 16 . After a one-week course in the Norwegian language, she started ninth grade in a regular classroom. When encouraged 


\section{Ragnar Arntzen and Odd Eriksen}

to recall her first memories as an immigrant in Norway, the 26-year-old Yasmin stated:

I was 16 years old and came from Moscow, where I had lots of friends all the time. Not to brag, but I was one of the popular students at school. I always had friends around me, and then I came to a small village, a small class, a completely different language. I could not express myself. It was absolutely terrible. I often say about that year that it was my worst year ever, and I experienced quite a lot in childhood.

When I think back on it, I'm almost a little embarrassed of myself. I'm a person who likes to participate, has always been very active in the classroom, been a good girl: "Raise your hand in class"! And then I found myself in the tenth grade, lying with my head on the desk like a slacker. It was embarrassing! I had a completely different role than I was used to.

Yasmin did not make any Norwegian-speaking friends that first year and had the impression that her fellow students wanted to keep to themselves. She told us that she practiced talking in front of a mirror: "I remember the first three words I learned: 'Hei', 'Vær', 'Fint'. I stood in front of the mirror in the bathroom every morning and practiced saying these words out loud: 'Hei, fint vær!' [Hi, nice weather!]. I didn't want to be a loser'. After a while, she felt that the teachers saw her talent and wanted to help her realise her potential:

I felt that they saw me. Like, "Here is a student who actually knows something", and they were thinking, "How can we get this knowledge out"? I really tried to show them that I wanted to succeed. It is not easy to cope; it's a struggle. But the teacher needs to know this as well-and express this to the student.

Yasmin felt that the mother-tongue support was of great help and found that it was much easier to understand information in Norwegian when the mother-tongue teacher reviewed the lessons first. Consequently, she found her schoolwork more interesting and motivating. In upper secondary school, Yasmin found that the educational system was more similar to the Russian system to which she was accustomed. She felt that she benefitted more from her previous knowledge and skills, especially in history and math: "I got good grades in history as I had learned world history in Russia. I studied the textbooks and did well orally, but it was more difficult to write. It helped a lot to have the oral tests instead of written". In upper secondary school, Yasmin also started to make Norwegian-speaking friends.

Yasmin recalled a smooth transition from upper secondary school to the university college and teacher education, but she was unhappy with her student group. The Norwegian-speaking students dominated, and she felt 
marginalised in the group. Yasmin remembered them as constantly complaining and focusing on irrelevant details and matters: "After the lectures, I tried to recall and repeat: What have I learned today? And the only thing I managed to remember was their complaints". She did not pass the firstyear examination and held her student group responsible, but also realised that it was her responsibility to do something about it: "Ok, now you are going to learn something; that's what it's all about. I thought about this when I was reading yesterday evening. Oh, I can remember yesterday's lecture very well. So things have changed-for the better".

Today, Yasmin teaches youth from Afghanistan and Iran who are about the same age she was when she arrived in Norway:

I understand their situation and have deep empathy. Several of them set high goals at once; they are ambitious and impatient and want to become engineers, doctors. Of course, they are allowed to have dreams, and in Norway, it is easier to realise one's dreams. But it's hard. One has to face reality, how things are. You are here, and there is the way. Believe me; it's hard. I have been through it.

The migrant process has shaped Yasmin's thinking and plans for her future and family: "I indeed want my children to speak Norwegian, of course, and Dari and Russian, my three main languages". For many years, Yasmin regarded Russian as her mother tongue. When her younger brother recently had a baby girl, Yasmin preferred to speak Dari with her and wanted her to learn Dari. Yasmin highlighted how the Internet and new social-media technologies have revived her fluency in Dari.

\section{Discussion}

Both Babet and Yasmin experienced migration as a radical break in their "educational run". Babet said that she did not benefit at all from earlier schooling in her homeland. Even though she received mother-tongue teaching and performed intensive exercises in Norwegian as a L2 during the transition period, this language support did not seem to bridge the gap between her previously acquired knowledge and her continuing education. One might claim that these experiences challenge the cognitive approach's basic ideas about how knowledge is acquired.

Bruner (1969) argues that new knowledge is developed based on alreadyacquired knowledge and that the transfer of both training and principles is the foundation of education. According to cognitive psychology (Bransford, Brown, and Cocking 2000, as cited in Haukås 2014), the human brain, whether consciously or unconsciously, continuously associates, compares, systematises, conceptualises and interprets new input based on earlier experiences. One can question the extent to which these processes transfer smoothly between the different languages in the mind of multilinguals. As 
mentioned above, it can be claimed that cognitive processes are influenced by students' threshold level of proficiency in the instructional language (Cummins 1976), especially in vocabulary (Rydland, Aukrust, and Fulland 2012; Lipka and Siegel 2012).

Babet said that she understood all the instructions and lessons in the lower secondary school, but had difficulties writing and translating between her L1 and L2. This problem might be connected to her language use and social life: Babet had no contact with ethnic Norwegians in her leisure time and preferred to be with friends with the same linguistic background, even at school. Furthermore, she had few opportunities to use the Norwegian language in formal academic activities, such as group work. Thus, her exposure to the Norwegian language might have been too limited to promote good L2 development. Developing rich, nuanced, precise vocabulary requires encountering and using new words in many different contexts and, of course, extensive exposure to both oral and written language.

Yasmin experienced her arrival in Norway as a more radical break from the past than Babet, who quickly met Kurdish-speaking peers, thus giving her a degree of social continuity. In contrast, Yasmin felt more alone and experienced-what we might call cultural shock. How she recalled her first period of time in Norway is revealing. She used a kind of double perspective, both visualising and reflecting, so the researchers could see how the teenage girl reacted to the situation and listen to how she interpreted and reflected on the experience in the present day. Yasmin clearly described how she, as a 16-year-old girl, responded to the humiliating school situation with her whole body. She observed herself through the eyes of other students and the teacher. She linked this experience to her language loss and changed student role. Whereas she perceived herself as an active, outgoing, popular girl before moving to Norway, she became passive and silent after moving. She vividly portrayed not only a (transitional) loss of language, but also the loss of a positive identity as a consequence of migration.

Yasmin not only reacted to the situation; she also reflected on what was going on and explored strategies to overcome the challenges. For instance, Yasmin used to practise language skills in front of a mirror. This exercise was not only language training, but also training for a new classroom role. Yasmin appeared to have been a very reflective girl, conscious of her role as a student, her own learning, and the dialogic relations between students and between teachers and students. Unlike Babet, Yasmin gradually found that knowledge acquired earlier in another language helped her, for instance, when learning world history in Norwegian. Building relations between earlier and new knowledge across languages is not only a linguistic act, but also demands activating acquired knowledge and reflecting on how to transfer this knowledge to new contexts (Haukås 2014). According to Anderson (2002), teachers should help students learn to think about what happens during the (language) learning process, rather than focus their attention 
solely on learning the new language. Doing this will lead to the development of stronger learning skills.

Both Babet and Yasmin had mother-tongue teaching, which is expected to assist students in transferring their previously acquired knowledge. Yasmin gradually experienced that preparatory work in some subjects and topics with the mother-tongue teacher helped her understand the lessons in the general classroom. Consequently, she became more motivated to do schoolwork. After a year or two, she also noticed that topics she had learned in Russian schools, such as world history, had relevance and could be used in the Norwegian lessons. Babet seems to have used her L1, on a daily basis, to a much larger extent than Yasmin after migration, but never perceived her L1 resources as relevant in Norwegian schooling and learning. More so, she found her mother-tongue instruction to be irrelevant to her learning in the regular classroom. In our view, these different experiences seem to indicate that mother-tongue support is more beneficial if the teaching is closely connected to what happens in the regular classroom, particularly in regard to subjects, issues, teaching methods and learning strategies.

Group work is an important instructional method throughout the Norwegian educational system. In university college studies, it is mandatory to participate in permanent, small student groups, which also must fulfil some course assignments together. Research on multicultural group work in education tends to show both positive and more challenging effects on student learning and social interaction (Popov et al. 2012). Group work can play a major role in metacognitive development as "interactions with others can provide the stimulus needed for the individual to become more aware of their cognitive processing" (Wertsch 1978, as cited in Larkin 2006, 8). Cooperative interaction is beneficial, inter alia, as students exchange views and argue, discuss and negotiate meaning, which promotes and develops metacognition (Zhang 2011). In a literary review, Popov et al. (2012) find that multicultural groups both lead to a less ethnocentric approach and prepare for working effectively in culturally heterogeneous groups. Learning an L2 in a migrant context is partly related to socialisation into new understandings and perspectives: "bilinguals may therefore have access to different conceptual representations, experience different imagery and index more varied discourses" (Baker 2006, 163). It is reasonable to believe that this multicultural competence can enrich conversations in discussion groups. On the other hand, research also points to challenges concerning conflicts and misunderstandings in multicultural groups; as a source for ineffective learning situations and decreased integration. Popov et al. (2012, 312) find several challenges connected to multilingual group work, such as free-riding, insufficient skills in the language of instruction and students not communicating properly.

Both Babet and Yasmin reported discouraging experiences with group work, regarding marginalisation, and that they were not seen as resources. 


\section{Ragnar Arntzen and Odd Eriksen}

Babet and Yasmin seemed to have experienced the learning environment as ethnocentric. Several other participants in the main study sample had similar experiences with working in groups. One participant in the project was in groups with only ethnic Norwegian students: "By working in groups, I became a bit invisible, and the other students told the teacher that I didn't want to speak with them." The participant had to change student groups four times. This problem was later "solved" by establishing a separate group with "foreigners", as she called it. These experiences correspond to Bourdieu's (1996) analysis of how the majority culture in a society establishes the legitimate culture and language, and thus marginalises all other cultures and languages.

Other studies on minority-language-speaking students have reported the same pattern. Martin's (2010) informants experienced exclusion in several episodes and situations and stated that many majority university students were reluctant to work with minority-language-speaking students in study groups. The informants in the previously mentioned Norwegian study (Berge 2012, 44) also described social exclusion—not explicit racism, but the feeling of being different and the absence of "someone to identify with". According to our participants, such social exclusion happened in the classroom and groups in both lower and higher education.

It is tempting to moralise about the attitudes and behaviours of the majority students. Instead, we point to teachers' and educators' responsibility to plan various working methods and processes. They need to handle assignments so as to encourage students to welcome and appreciate diverse perspectives and cross-cultural experiences. However, group work can be perceived as a demanding pedagogical method for students with little or no previous experience with this kind of study work. Steinsvik and Hilditch (2014) explain that students with educational backgrounds in some parts of the world often lack experiences with democratic studying methods that involve group discussions and cooperation. Teachers should be aware of this culturally determined factor when selecting their pedagogical approaches. It is also important that teachers define group work as training for teamwork in future professional careers. There is great empirical support for the positive influence cultural diversity in universities has on educational experiences that help students prepare for participation in an increasingly diverse world (Astin 1993; Bowen and Bok 1998 in Denson and Bowman 2013, 557). To make sure that these kinds of culturally heterogeneous groups can be a foundation for learning and social integration, both students and teachers need to be aware of the factors that impact group dynamics and thus deal constructively with challenges arising from diversity (Popov et al. 2012).

\section{Conclusion}

In this chapter, we have presented two migrant students' stories of their education in order to obtain multicultural perspectives on the Norwegian 
educational system and determine how these students experienced the transition from one system to another during their educational career. The students highlighted the transversal events that have shaped their lives. They experienced migration as a radical break in their educational careers. For both, this was the first time they had reflected on this aspect of their lives. The impression is that the Norwegian educational system did not seem well prepared to meet the pedagogical and social needs of migrant students. Both participants had language support in their mother tongue along with L2 learning, but these activities were not well coordinated with regular teaching and learning activities. The participants encountered social exclusion by majority-speaking students in social learning activities and a lack of recognition of their prior knowledge from either fellow students or teachers.

In life stories, the two students focused on quite similar challenges, but selected different coping strategies. The students' reflections indicate that their choice of strategies, as much as the events per se, influenced their development. Babet had constant access to friends with the same cultural background. Looking back, she found that this eased the pain of transition, but was not a useful strategy for coping with future challenges and integration. Yasmin had no friends on whom to lean and experienced the first period of time in Norway as painful. Her abilities to analyse and reflect upon challenges and explore different metacognitive strategies became valuable resource in her academic career.

This type of narrative inquiry is, in a way, an approach to understanding and learning from students' experiences of learning and metacognition. This information can also inform teachers and teacher educators about how to better include multilingual students both socially and in learning outcomes. Teachers at all levels could benefit from greater awareness of the need to support students' struggle for educational continuity. It is essential for migrant students to learn and be trained in how to connect prior language and subject-matter knowledge with the content presented in their new learning environment. This issue is related to teachers' attitudes towards minority-language-speaking students' use of multilingual resources in the classroom. Minority-language-speaking students with a common L1 should be encouraged to use it, to a certain extent, in conversations and group work in the general classroom. Students can also read textbooks in their $\mathrm{L} 1$, write notes and reflections in their L1, or present texts or issues in their L1 for their fellow students with a common L1. Developing and activating metacognitive competence in a multilingual classroom also implies activating multilingual resources. Teachers should awaken multilingual students' awareness of the benefits of prior knowledge and teach them strategies to access it. The starting point of these processes is for teachers to encourage students to share their experiences and tell their stories.

These two students' stories do not present the whole picture or the foundation for drawing conclusions about education and migration. Self-reporting and memory loss over time are linked to challenges regarding inquiry 


\section{Ragnar Arntzen and Odd Eriksen}

research. The school and the educational system change, and it is a relevant question how these stories reflect challenges in the present time.

It was therefore important to address this issue by comparing our data with other studies. Our prejudices and biases might have influenced the way we handled the interviews and analysed the transcriptions. To minimise this, we openly discussed our own personal and political background before and after the data collection (Creswell 2013, 76) with the students. Furthermore, we sent the transcriptions and this chapter to the participants for member validation (Silverman 2010, 276) and encouraged them to comment.

Despite the above-mentioned limitations, we still believe these individual voices do offer interesting perspectives that can increase our understanding of contemporary education in an increasingly multicultural und multilingual society.

\section{References}

Adesope, Olusola O., Tracy Lavin, Terri Thompson, and Charles Ungerleider. 2010. "A Systematic Review and Meta-Analysis of the Cognitive Correlates of Bilingualism." Review of Educational Research 80 (2): 207-45. https://doi. org/10.3102/0034654310368803

Anderson, Neil J. 2002. The Role of Metacognition in Second Language Teaching and Learning. Washington, DC: Center for Applied Linguistics, ERIC Clearinghouse on Languages and Linguistics.

Astin, Alexander W. 1993. "Diversity and Multiculturalism on the Campus: How Are Students Affected?” Changes: The Magazine of Higher Learning 25 (2): 44-9. https://doi.org/10.1080/00091383.1993.9940617

Baker, Colin. 2006. Foundations of Bilingual Education and Bilingualism. Clevedon: Multilingual Matters.

Bakken, Anders. 2007. "Ungdomsskolens klasseskiller [Social Distinctions in Lower Secondary School]." In Ung i Norge: Skole, fritid og ungdomskultur [Young in Norway: School, Leisure Time and Youth Culture], edited by Åse Strandbu and Tormod Øia, 42-61. Oslo: Cappelen Damm Akademisk.

Berge, Hanne. 2012. "Fra tospråklighet til ettspråklighet. Om en flerspråklig oppvekst og den flerspråklige livssituasjonen blant minoritetsspråklige studenter i høyere utdanning [From Bilingualism to Monolingualism. On Multilingual Adolescence and the Multilingual Life Situations among Minority Speaking Students in Higher Education].” M.A. thesis. Department of Psychology, University of Oslo.

Berggreen, Harald, and Sirkku Latomaa. 1994. "Språkbytte og språkbevaring blant vietnamesere i Bergen og Helsinki [Language Shift and Language Maintenance among Vietnamese in Bergen and Helsinki]." In Sprogbrug og sprogvalg blant invandrere $i$ Norden [Language Use and Language Choice Among Immigrants in the Nordic Countries], edited by Sally Boyd, Anne Holmen, and Jens N. Jørgensen, 137-80. København: Danmarks lærerhøjskole.

Bialystok, Ellen. 1988. "Levels of Bilingualism and Levels of Linguistic Awareness.” Developmental Psychology 24 (4): 560-7. https://doi.org/10.1037/00121649.24.4.560 
Bialystok, Ellen, and Gregory J. Poarch. 2014. "Language Experience Changes Language and Cognitive Ability." Zeitschrift für Erziehungswissenshaft 17 (3): 433-46. https://doi.org/10.1007/s11618-014-0491-8

Bourdieu, Pierre. 1996. Symbolsk makt [Symbolic Power]. Oslo: PAX Forlag AS.

Bowen, William, and Derek C. Bok. 1998. The Shape of the River: Long-term Consequences of Considering Race in College and University Admissions. Princeton, NJ: Princeton University Press.

Breckner, Roswitha. 2005. Migrationserfahrung-Fremdheit-Biografie. Zum Umgang mit polarisierten Welten in Ost-West-Europa. Wiesbaden: VS Verlag.

Bronfenbrenner, Urie. 2005. Making Human Beings Human. London: Sage Publications.

Bransford, John D., Ann L. Brown, and Rodney R. Cocking. 2000. How People Learn: Mind, Brain, Experience, and School. Washington, DC: National Academy Press.

Bruner, Jerome S. 1969. The Process of Education. Cambridge: Harvard University Press.

Carlisle, Joanne F., Margaret Beeman, Lyle H. Davis, and Galila Spharim. 1999. "Relationship of Metalinguistic Capabilities and Reading Achievement for Children Who Are Becoming Bilingual." Applied Psycholinguistics 20 (4): 459-78.

Clandinin, D. Jean, and F. Michael Connelly. 2000. Narrative Inquiry. San Francisco: John Wiley \& Sons Inc.

Creswell, John W. 2009. Research Design: Qualitative, Quantitative, and Mixed Methods Approaches. 3rd ed. London: Sage Publications.

- 2013. Qualitative Inquiry \& Research Design. London: Sage Publications.

Cummins, Jim. 1976. "The Influence of Bilingualism on Cognitive Growth: A Synthesis of Research Findings and Explanatory Hypotheses." Working Papers on Bilingualism 9, 1-43.

- 2000. Language, Power and Pedagogy: Bilingual Children in the Crossfire. Clevedon: Multilingual Matters.

Denson, Nida, and Nicholas Bowman. 2013. "University Diversity and Preparation for a Global Society: The Role of Diversity in Shaping Intergroup Attitudes and Civic Outcomes." Studies in Higher Education 38 (4): 555-70. https://doi.org/10. 1080/03075079.2011.584971

Fillmore, Lily W. 2000. "Loss of Family Languages: Should Educators Be Concerned?” Theory Into Practice 39 (4): 203-10. https://doi.org/10.1207/s15430421 tip3904_3

Haukås, Åsta. 2014. “Metakognisjon: Om språk og språklæring i et flerspråklighetsperspektiv [Metacognition: On Language and Language Learning from a Multilingual Perspective].” Acta Didactica Norge 8 (2): 7.

- 2015. "A Comparison of L2 and L3 Learners' Strategy Use in School Settings." Canadian Modern Language Review 71 (4): 383-405. https://doi. org/10.3138/cmlr.2701

- 2016. “Teachers' Beliefs about Multilingualism and a Multilingual Pedagogical Approach.” International Journal of Multilingualism 13 (1): 1-18. https:// doi.org/10.1080/14790718.2015.1041960

- 2018. "Metacognition in Language Learning and Teaching: An Overview." In Metacognition in Language Learning and Teaching, edited by Åsta Haukås, Camilla Bjørke, and Magne Dypedahl. New York: Routledge. 


\section{Ragnar Arntzen and Odd Eriksen}

Jessner, Ulrike. 2018. "Metacognition in Multilingual Learning: A DMM Perspective." In Metacognition in Language Learning and Teaching, edited by Åsta Haukås, Camilla Bjørke, and Magne Dypedahl. New York: Routledge.

Kulbrandstad, Lars A. 1997. Språkportretter. Studier av tolv minoritetselevers språkbruksmønstre, språkholdninger og språkferdigheter [Language Portraits: Studies on Twelve Minority Pupils' Language Use Patterns, Language Attitudes and Language Skills]. Vallset: Oplandske Bokforlag.

Larkin, Shirley. 2006. "Collaborative Group Work and Individual Development of Metacognition in the Early Years." Research in Science Education 36: 7-27. https://doi.org/10.1007/s11165-006-8147-1

Lipka, Orly, and Linda S. Siegel. 2012. "The Development of Reading Comprehension Skills in Children Learning English as a Second Language." Reading and Writing 25: 1873-98. https://doi.org/10.1007/s11145-011-9309-8

Lutz, Helma. 2011. "Lost in Translation? The Role of Language in Migrants' Biographies: What Can Micro-Sociologists Learn from Eva Hoffman?” European Journal of Women's Studies 18 (4): 347-60. https://doi.org/10.1177/1350506811415195

Martin, Peter. 2010. “'They have lost their identity, but not gained a British one': Non-Traditional Multilingual Students in Higher Education in the UK." Language and Education 24 (1): 9-20. https://doi.org/10.1080/09500780903194028

Montrul, Silvina. 2008. Incomplete Acquisition in Bilingualism: Re-examining the Age Factor. Amsterdam: John Benjamins.

Moore, Daniele. 2006. "Plurilingualism and Strategic Competence in Context." International Journal of Multilingualism 3 (2): 125-38. https://doi.org/10.1080/ 14790710608668392

Oropeza, Maria V., Manka M. Varghese, and Yasuko Kanno. 2010. "Linguistic Minority Students in Higher Education: Using, Resisting, and Negotiating Multiple Labels." Equity \& Excellence in Education 43 (2): 216-31. https://doi.org/10. 1080/10665681003666304

Pauwels, Anna. 2016. Language Maintenance and Shift: Key Topics in Sociolinguistics. Cambridge: Cambridge University Press.

Peal, Elisabeth, and Wallace E. Lambert. 1962. "The Relation of Bilingualism to Intelligence." Psychological Monographs: General and Applied 76 (27): 1-23. https://doi.org/10.1037/h0093840

Popov, Vitaliy, Dine B. Brinkman, Harm J. A. Biemans, Martin Mulder, Andrei Kuznetsov, and Omid Noroozi. 2012. "Multicultural Student Group Work in Higher Education. An Explorative Case Study on Challenges as Perceived by Students." International Journal of Intercultural Relations 36: 302-17. https://doi. org/10.1016/j.ijintrel.2011.09.004

Pran, Kristin R., and Linn S. Holst. 2015. Rom for språk? [Room for Language?] Språkrådet: Rapport.

Rydland, Veslemøy, Vibeke G. Aukrust, and Helene Fulland. 2012. "How Word Decoding, Vocabulary and Prior Topic Knowledge Predict Reading Comprehension. A Study of Language-minority Students in Norwegian Fifth Grade Classrooms." Reading and Writing 25 (2): 465-82. https://doi.org/10.1007/ s11145-010-9279-2

Silverman, David. 2010. Doing Qualitative Research. 3rd ed. London: Sage Publications Ltd.

Statistics Norway. 2013a. Befolkningens utdanningsnivå, etter spørreundersøkelse om utdanning fullfort i utlandet [Population's Level of Education, After Survey 
on Education Abroad]. Rapporter 24/2013. Accessed August 20, 2017. www.ssb. no/utdanning/artikler-og-publikasjoner/_attachment/115532?_ts=13f0ed11d68

_.2013b. Minoritetsspråk i Norge: En kartlegging av eksisterende datakilder og drøfting av ulike fremgangsmåter for statistikk om språk [Minority Languages in Norway: A Mapping of Existing Data Sources and Discussion of Different Approaches for Language Statistics]. Oslo: Statistisk sentralbyrå 8/2013. Accessed at August 20, 2017. www.ssb.no/utdanning/artikler-og-publikasjoner/ minoritetsspraak-i-norge

2017. Nøkkeltall for innvandring og innvandrere [Key Figures for Immigration and Immigrants]. Accessed August 20, 2017. www.ssb.no/innvand ring-og-innvandrere/nokkeltall/innvandring-og-innvandrere

Steinsvik, Brit, and Grethe Hilditch. 2014. "Tospråklige lærerstudenters erfaringer med gruppearbeid: Skremmende og konfliktfylt eller demokratisk og lærerikt? [Bilingual Teacher Students' Experiences with Group Work: Frightening and Conflicting or Democratic and Instructive?]. Cepra-striben-tidsskrift for evaluering i praksis 16: 77-85.

Stølen, Gerd. 2013. "Livshistorier: et biografisk perspektiv i pedagogisk forskning." [Life Stories: A Biographical Perspective in Pedagogical Research] In Loreren som forsker [The Teacher as a Researcher], edited by Mary Brekke and Tom Tiller, 233-44. Oslo: Universitetsforlaget.

Wertsch, James V. 1978. "Adult-child Interaction and the Roots of Metacognition." Quarterly Newsletter of the Institute for Comparative Human Development 2: 15-18.

Yosso, Tara J. 2005. "Whose Culture Has Capital? A Critical Race Theory Discussion of Community Cultural Wealth." Race, Ethnicity and Education 8 (1): 69-91. https://doi.org/10.1080/1361332052000341006

Zhang, Lawrence J. 2011. "Negotiating Language, Literacy and Identity: A Sociocultural Perspective on Children's Learning Strategies in a Multilingual ESL Classroom in Singapore." In Applied Linguistics Review, edited by Li Wei, 247-70. Berlin/New York: De Gruyter. 